\title{
THE UNCANNY: DEVELOPMENT AND PERSPECTIVES ON THE PUTURE
}

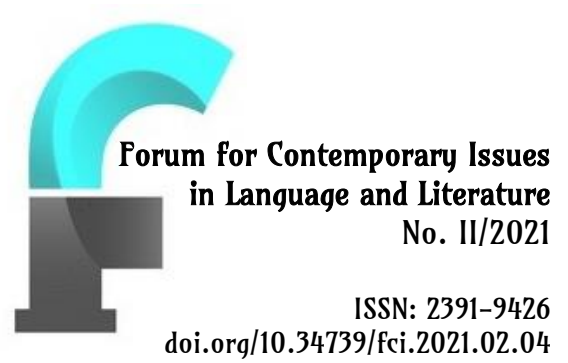

\author{
Aleksandra Mrówczyńska
}

ORCID: 0000-0002-0638-2463

Kazimierz Wielki University in Bydgoszcz

\begin{abstract}
In 1919 Sigmund Freud raised the interest in the uncanny by claiming in his essay "Das Unheimliche" that something can be familiar and unfamiliar at the same time. Since the emergence of the concept in the 20th century, many scholars have presented their own definition of the uncanny. The concept originates from the German unheimlich but the meaning reaches far beyond its dictionary definition. As Masschelein suggests, the word itself "is untranslatable qua form and content" (Masschelein 2011, 7) and as long as the uncanny cannot be understood literally, the ambiguity of the term can lead to a multitude of interpretations. The aim of this paper is to explore how the perception of the uncanny has been changing through the years in connection with the Freudian definition. The paper offers an overview of various interpretations of the concept starting from 1906 until today. The juxtaposition of the most significant views on the uncanny shows how the concept has gradually formed a basis for various fields of study such as literature and art. The paper presents future perspectives of the uncanny where it no longer refers only to the motif of the double or supernatural elements but it also tackles the problems of body transformations and politics.
\end{abstract}

\section{Key words}

Derrida, Cixous, the uncanny, Sigmund Freud, Ernst Jentsch, Mori, Todorov

\section{Introduction}

Sigmund Freud laid the groundwork for the perception of the uncanny as a concept. The publication of his pivotal essay "The Uncanny" in 1919 contributed to the classification of the term as an aesthetic category (Masschelein 2011,3). Freud aroused theorists' interest in this subject and in the course of time many of them have attempted to present their own understanding of the word uncanny. Eventually, some of them came to the conclusion that the expression "is untranslatable qua form and content" and "the same feeling can be expressed by words such as 'creepy', 'eerie'[and] 'weird'” (Masschelein 2011, 7). The ambiguity of the term and the dualistic nature of the uncanny provide an opportunity for arbitrary interpretations of the concept, the understanding of which has been changing throughout the years. Hence, 
the ideas represented by the uncanny have become a starting point for the theory of deconstructionism, feminism, the question of sexual identity and the uncanny valley. This article offers a systematic overview of the beginnings of the concept, the developments and the possibilities for the future research.

\section{The Beginnings of the Uncanny: Ernst Jentsch and Sigmund Preud}

Crucial to identifying the uncanny as a concept in philosophical and theoretical discourse is the essay "On the Psychology of the Uncanny" published in 1906 (Masschelein 2011, 3). Ernst Jentsch refers in his paper to the German word unheimlich, indicating "that someone to whom something 'uncanny' happens is not quite 'at home' or 'at ease' in the situation concerned, that the thing is or at least seems to be foreign to him" (Jentsch 2008, 217). He introduces the theory of intellectual uncertainty in order to explain how certain feelings, such as "mistrust, unease and even hostility", are responsible for evoking the effect of the uncanny in connection with "the new and the unusual" (Jentsch 2008, 218). As a result, he provides numerous examples to support his statement. According to Jentsch, "an extremely uncomfortable feeling" (Jentsch 2008, 220) can be achieved due to disguises and masks because of people's incapability of "becoming accustomed" (Jentsch 2008, 220). Even if people know that they are deceived by their imagination, they usually cannot overcome this strong feeling of uncertainty. A similar situation occurs when people are unable to identify whether, a given object is animate or inanimate, which leaves an imprint on their consciousness (Jentsch 2008, 220-221).

Jentsch's commentary on the nature of objects constitutes a significant part of his essay. According to him, things such as wax figures or machines resemble animate objects simply because of their strong resemblance to human beings. Due to technological advances they can produce sounds, do household chores, serve other people and entertain them. The machines' ability to imitate human beings provokes the feeling of uncanniness, the effect of which can be intensified by their human-like appearance (Jentsch 2008, 222-223). Jentsch points out that the authors often use this strategy in their literary texts to make readers uncertain if they deal with a living being or rather with an object. One such example that Jentsch introduces is "The Sandman" by E.T.A Hoffmann where "the doubtful tension [...] is made serviceable by the virtuosic manipulation of the author for the purposes of artistic investigation" (Jentsch 2008, 224). The fantasy has a powerful impact on readers' imagination to the extent that "a lonely lake" turns out to be "the gigantic eye of a monster and the outline of a cloud [...] becomes a threatening Satanic face" (Jentsch 2008, 224). The tendency to imagine potentially hazardous phenomena is triggered by darkness or the state of intoxication. Literary figures can hallucinate under the influence of psychoactive substances and due to their vivid imagination they can converse with imaginary objects. Jentsch claims that it is a common practise among storytellers as 
they use this device to "push the play with the reader's psychical helplessness" (Jentsch 2008, 225). The reader usually discovers at the end of the story that the whole experience of uncanny nature is just the protagonist's vision caused by hallucination (Jentsch 2008, 224-225). Indeed, literature has a strong impact on the imagination, but Jentsch suggests that people generally have an innate predisposition to perceive objects as living beings: "The child of nature populates his environment with demons; small children speak in all seriousness to a chair, to their spoon, to an old rag and so on, [...]. Even in highly cultivated Greece, a dryad still lived in every tree" (Jentsch 2008, 225). They become victims of their imagination because they feel constantly threatened by something they are unable to explain. This tendency, however, seems to decline with age as people's ability to think reasonably increases (Jentsch 2008, 225). Coming to the end of the essay, Jentsch once more emphasizes the significant role of intellectual uncertainty in the emergence of uncanny feelings. According to the author, a state of mind where there is no place for doubts is necessary to receive "a psychical shelter" that can help "in the struggle for existence" (Jentsch 2008, 227).

Freud directly responds to many of those remarks in his "The Uncanny", commenting however that Jentsch's essay is "a fertile but not exhaustive paper" (Freud 1919, 1). In fact, ideas introduced by Jentsch form the basis for Freud's later study on the uncanny but eventually he decides to use the "theme of the 'Sand-Man' who tears out children's eyes” (Barnaby 2015, 980 after Freud 1919, 5). It constitutes a significant shift from Jentsch's key concept of intellectual uncertainty to a short story written by E.T.A. Hoffmann, which was only briefly mentioned in Jentsch's essay on the uncanny (Barnaby 2015, 979-980). Freud's analysis of the fear of losing one's eyes directly leads to the discussion of castration and Oedipus complex: "A study of dreams, phantasies and myths has taught us that a morbid anxiety connected with the eyes and with going blind is often enough a substitute for the dread of castration" (Freud 1919, 7). Freud adds novelty to the concept by seeking answers to such questions as "why does Hoffmann bring the anxiety about eyes into such intimate connection with the father's death?" or "why does the Sand-Man appear each time in order to interfere with love?" (Freud 1919, 8). Freud noticed the close relationship between the unconsciousness and sexuality, which became a prototype for the psychoanalytic order of the symbolic. According to Nobus, the selection of this particular theme might suggest that Freud perceives discourse on the uncanny as a competition between him and Jentsch in order to become the only scholar who invented the concept (Nobus 1993a: 62-63 after Masschelein 2011, 18-19).

Freud refers at the beginning of "The Uncanny" to the origins of the word unheimlich, emphasizing the role of its antonym in the understanding of the concept. It is worth mentioning that he was the first person to do so, as Jentsch did not focus on the linguistic side of the word. He provides a detailed analysis preceded by the following definitions of the word Heimlich, which according to Wörterbuch der deutschen Sprache means: "belonging to the house or the family", "friendly, intimate, 
homelike", "tame, companionable to man" with reference to animals and "concealed, kept from sight, so that others do not get to know about it, withheld from others" (Freud 1919, 2-3). The latter representation of the word constitutes the core of Freud's understanding of the uncanny. The following extract shows that both words can in fact be used interchangeably: "Unheimlich' is the name for everything that ought to have remained ... hidden and secret and has become visible" (Freud 1919, 4). Freud notices that even though the words represent the opposites, they still coincide with each other to the extent that "what is heimlich thus comes to be unheimlich" (Freud $1919,4)$. In this case, the negative prefix that appears in the word unheimlich functions not as a lexical negation but rather as a reminder that "even when something is negated, it still remains present in the unconscious" (Masschelein 2011, 8).

Freud presents a thorough analysis of "The Sandman", as this story constitutes the centre of his reflections on the nature of the uncanny. During his re-reading of the story, he shows much appreciation for Hoffmann and his work. Freud calls "The Sandman" a "fantastic tale" (Freud 1919, 5) and compliments the author by giving him the title of "the unrivalled master of conjuring up the uncanny [...] in literature" (Freud 1919, 9). Freud even dares to say that Hoffmann is "a writer who has succeeded better than anyone else in producing uncanny effects" (Freud 1919, 5). Hoffmann uses the word unheimlich multiple times in "The Sandman" but Freud does not relate to that (Royle 2003, 45). He uses the story to prove that the uncanny effect of certain phenomena does not arise from the concept of intellectual uncertainty to the extent that his "reading [...] [becomes] a violent attempt to reduce the significance of Jentsch's work on the uncanny" (Royle 2003, 41). Cixous also comes to the conclusion that Freud's attitude towards Jentsch's intellectual uncertainty resembles "a repression of the repression" merely due to the fact that "Jentsch say[s] more than what Freud wishes to read" (Cixous 1976, 534). Freud begins with a broad description of the novella that he calls a "short" one (Freud 1919, 7) but the fact that his summary is three-pages long and the original story has approximately twenty pages might be in fact recognised as an exaggeration. However, Freud's re-reading of the story became a starting point for other analysis (Royle 2003, 41) but many scholars perceive his interpretation as a manipulation of "the data and the text" (Masschelein 2011,109). As Royle puts it, it seems that it is Freud's "own 'short story' [because] he recounts [it] as if it were an objective, disinterested, merely 'factual' summing up” (Royle 2003, 40).

The nonlinear plot of "The Sandman" is recounted by multiple narrators and as the story progresses the reader has the opportunity to meet various literary figures that bear a strong resemblance to the title character (Royle 2003, 39-40). Freud in his analysis comes to the conclusion that the Sandman and the fear of losing one's eyes that results from his actions become the main source of uncanny feelings because of their metaphorical connection with the castration-complex: "a morbid anxiety connected with the eyes [...] is [...] a substitute for the dread of castration" (Freud 1919, 7). By drawing such a conclusion, he undermines the significance of inanimate objects 
for creating the uncanny effect, which was the centre of Jentsch's research on the concept. Freud justifies his choice by saying that the "uncertainty whether an object is living or [not] [...] is quite irrelevant in connection with this other, more striking instance of uncanniness" (Freud 1919, 7). At this point, Freud fails to understand that there is more to how Jentsch perceives the concept than just doubts related to the matter whether an object is alive or not (Barnaby 2015, 981). Jentsch raised the question of "aliveness [and] how we respond to our own confusion regarding that issue” (Barnaby 2015, 981), which Freud does not take into consideration in his interpretation of the uncanny. Freud builds his uncanny theory on Jentsch's ideas, hence in his later analysis he focuses on the doll Olympia but his point of view differs from Jentsch's. Freud claims that people treat such objects as living beings to the extent that they actually want them to be alive. He considers such behaviour as "an infant wish or [...] an infant belief" that he propagates using various examples (Freud 1919 , 9). The infantile factor can also be tracked down in the motif of the double. According to Freud, seeing an identical person in terms of appearance might be an eerie experience (Freud 1919, 9). He claims that this phenomenon is closely related to the ego by "present[ing] a missing link in the development of the ego-ideal" (Masschelein 2011, 41). It means that the body, mind and the soul have become separate elements that are presented in the form of the double (Masschelein 2011, 29) that Freud claims to be "a vision of terror" (Freud 1919, 10). He bears out his theory with Rank's definition of the double that "probably the 'immortal' soul was the first 'double' of the body" (Freud 1919, 9). Freud also ascribes the "principle of a repetitioncompulsion", which he thoroughly describes in Beyond the Pleasure Principle, to "infantile psychology" (Freud 1919, 11). It leaves no doubts that the repetition of "the same situations, things and events" that happen in "certain circumstances" (Freud $1919,10)$ is the source of uncanny feelings. Freud refers to such situations as ending up in the same street or coming across the same number. The above mentioned events are accompanied by the feeling of helplessness that comes from the belief that something is inevitable (Freud 1919, 11).

The last definition of the word unheimlich that was introduced in Freud's essay leads to other theories on the source of uncanny feelings. Freud claims that supernatural elements and certain phenomena that are linked to them could be responsible for the creation of such a feeling. He thinks that "our original emotional reaction to it, and the insufficiency of our scientific knowledge about it" (Freud 1919,13) are to blame for the uncanny effect. According to Freud, religious texts and institutions propagate the belief in various forms of life after death, which is additionally strengthened by non-religious sources that claim that "a contact [with the other sidel is not utterly impossible" (Freud 1919, 14). People are frightened of death and the paranormal. They tend to be afraid of their departed ones who might one day carry them off in order to share their life together. Freud also classifies such illnesses as epilepsy and madness as belonging to the same category: he claims that 
these disorders emerge from the act of supernatural forces (Freud 1919, 14). However, Freud ascribes the ability to create the most powerful uncanny effect to "the idea of being buried alive" (Freud 1919, 14) or the fear of being harmed. It is not necessary to verbalise bad intentions because they are usually betrayed in people's look, hence it is called "the dread of the evil eye" (Freud 1919,12). Secret thoughts can be easily put into action, which makes it a common superstition (Freud 1919, 12).

\section{The Uncanny After Preud}

After the publication of "The Uncanny", Freud rarely commented on the concept and it seems that other scholars initially did not show much interest in the uncanny either. The only exceptions are Otto Rank and Theodor Reik. Their interests revolve around the motif of the double, which they use to develop their own conlusions (Masschelein 2011, 50). Rank's The Double contains a multiplicity of examples to support his view that "the double was a defence from the anxiety of death" (Seulin 2020, 10), while Reik's The Strange God and One's Own God uses the same motif to examine religious issues (Masschelein 2011, 50). In the 1970s the concept of the uncanny attracted deconstructionists' attention, whose primary strategy concerns focusing on the marginal in a text, and, in fact, "The Uncanny", perfectly fulfils this criterion. Derrida in The Double Session, Todorov in The Fantastic. A Structural Approach to a Literary Genre and Hélène Cixous in "Fiction and Its Phantoms" took a fresh look at the concept as they contributed to development of the uncanny in literary criticism, politics and theory of feminism and, thereby they changed how the uncanny was perceived in the future (Masschelein 2011, 73, Royle 2003, 25).

Todorov introduced in The Fantastic the theory of a literary genre, whose primary function is to invoke a feeling of hesitation in the reader. It is possible to find an analogy to Jentsch's intellectual uncertainty, as Todorov claims that "the text must oblige the reader [...] to hesitate between a natural and a supernatural explanation of the events described" (Todorov 1973, 33). The author puts emphasis on the role of the reader's attitude in the process of reading: "The fantastic implies, then, not only the existence of an uncanny event, which provokes a hesitation in the reader and the hero; but also a kind of reading, which [...] must be neither 'poetic' nor 'allegorical"' (Todorov 1973, 32). Todorov notices the importance of fear in the creation of the fantastic simultaneously rejecting it as an indispensible element of the genre (Todorov 1973, 35). However, as long as it produces such negative emotions and evokes the feeling of hesitation in the reader, it might be compared to Jentsch's notion of "psychical helplessness" (Jentsch 2008, 225). According to Todorov, the place of the fantastic is "between the genres of 'the uncanny' and 'the marvellous" to the extent that there is no separate genre but rather "the uncanny', 'the fantastic-uncanny', 'the fantastic-marvellous' and 'the marvellous"' (Masschelein 2011, 80-81). Todorov's perception of the uncanny differs from Freud's, which he explicitly expresses in his 
commentary on E.A. Poe's "The Fall of The House of Usher", where he claims that "[Freud's] hypotheses [are] still to be verified" (Masschelein 2011, 81). However, the ambiguity which appears in Freud's text creates a link between the literature of the fantastic and the uncanny, which could be achieved, again, due to "the notion of 'hesitation' [that] allows for a shift of the uncanny towards the fantastic" (Masschelein 2011, 94). The motifs of the fantastic and the uncanny seem to be intertwined as Todorov claims that "the themes of the fantastic have become, literally, the very themes of the psychological investigation of the last fifty years" (Masschelein 2011, 91). It seems though that the key role in the perception of Todorov's The Fantastic through the prism of Freud's "The Uncanny" is played by the translator's choice of words. The word the uncanny already had its equivalent in French, which is l'inquiétante étrangeté. The translator, however, decided to translate the word l'étrange as the uncanny, even though it rather means the strange Masschelein claims that "this translation has generated a form of stickiness that had major consequences" (Masschelein 2011, 82). Todorov rarely mentions Freud's essay in The Fantastic but he supports his view with other examples such as The Double and The Strange God and One's Own God that directly respond to Freud's ideas. As a result, the uncanny became a significant part of Todorov's work and the concept itself is nowadays "regarded as an excellent tool to analyse the effects of the fantastic" (Masschelein 2011, 91, 94).

Derrida, on the other hand, focuses in his essay on "the themes of doubling [and] repetition”, which were central aspects of the Freudian uncanny. Derrida, in his analysis of Plato's and Mallarmé's work applies these themes together with "the effacement of limits" in order to find "[a link] between reality, fiction and truth" (Masschelein 2011, 112-113). He mentions "The Uncanny" as he claims that certain words are undecidable in terms of lexical ambivalence. According to Derrida:

\footnotetext{
We find ourselves constantly being brought back to that text by the paradoxes of the double and of repetition, the blurring of the boundaries lines between 'imagination' and 'reality', between the 'symbol' and the 'thing it symbolizes'..., the references to Hoffmann and the literature of the fantastic, the consideration on the double meaning of words [...] (to be continued) (Derrida 1981, 220 after Masschelein 2011, 113).
}

As Derrida promised in the passage quoted, he continued his reflections on the uncanny in 1993 in Spectres of Marx (Royle 2003, 25). This is a thought-provoking study about Marxism and the world's future after the collapse of the Soviet Union, where the uncanny is presented as "destabilizing concept" that "disturbs the ethical and the political order" (Masschelein 2011, 138). However, what is important for the concept of the uncanny is that Derrida takes into consideration the supernatural elements such as ghosts and spirits. He claims that the apparitions are the signifier of the future, not the past, which can also be applied to communism and democracy (Royle 2003, 67). For Derrida, the uncanny stands for: 
a stranger who is already found within (das Heimliche-Unheimliche), more intimate with one than one is oneself, the absolute proximity of a stranger whose power is singular and anonymous (es spukt), an unnameable and neutral power, that is, undecidable, [...] and identity that [...] invisibly occupies places belonging finally neither to us nor to it” (Royle 2003, 68).

Derrida implies that all ideas presented in Spectres of Marx are "a matter of the uncanny" to the extent that the paper could have been called "Marx - das Unheimliche" (Royle 2003, 128). It seems that Derrida's works are haunted by the Freudian concept and as a result he coins a new term hauntology that means "[the haunt and] the return of the repressed, in which the spectral takes precedent over being, existence" (Masschelein 2011, 139, Royle 2003, 128). Moreover, he emphasized another important aspect of his theory, which is "to haunt does not mean to be present" (Derrrida 1994, 202). The new philosophy refers to "techno-hermeneutics" or "technologics" that describe "logics that shape and govern our contemporary society in which classical notions of time, space, and unity of the subject have disappeared" (Masschelein 2011, 146). Hauntology is characterized not only by scepticism towards technological advances but also by nostalgia. This sentimental longing is revealed in the constant returning of theorists to exemplary works of Freud and Derrida, which they analyse in order to solve the issues of time (Masschelein 2011, 146).

Hélène Cixous is another deconstructionist who offered a conceptualization of the uncanny by creating a close link between the uncanny, literature, queer studies and theory of feminism. In her essay "Fiction and Its Phantoms", she also tackles the problems concerning homosexuality and sexual identity. She claims that placement of the doll Olympia in a footnote of Freud's "The Uncanny" is rather a "typographical metaphor of repression" (Cixous 1976, 537 after Royle 2003, 42) and "it is a matter [...] of turning the episode involving Olympia into satire, thus managing to eclipse and obscure it" (Cixous 1976, 532). According to Cixous, Freud's view on the doll concerning that she "can be nothing else than a materialization of Nathaniel's feminine attitude towards his father in his infancy" (Freud 1919, 8) refers to "homosexuality" (Cixous 1976, 538 after Royle 2003, 42). She strongly summarizes Freud's choice of the Sandman and the diminishment of the Olympia's role in the production of the uncanny with the following words: "We get sand thrown in our eyes, no doubt about it” (Cixous 1976, 532). As a consequence of Freud's shift towards the title character of Hoffmann story and the focus on castration-complex, the uncanny became a subject of feminist discussions. Cixous also analyses the queer characteristics of "The Uncanny" not through the prism of contemporary meaning of the word but rather in the sense of

the open mesh of possibilities, gaps, overlaps, dissonances and resonances, lapses and excesses of meaning when the constituent elements of anyone's gender, of anyone's sexuality aren't made (or can't be made) to signify monolithically (Kosofsky Sedgwick 1994, 8 after Royle 2003, 42). 
Cixous comes to the conclusion that heimlich and unehimlich become an androgyne: possessing both masculine and feminine features. From her point of view homo- and hetero- coincide with one another exactly in the same way as heimlich and unheimlich in Freund's analysis, which shows that the uncanny and uncertainties about sexual identity seem to be somehow intertwined (Royle 2003, 42-43).

\section{Contemporary Approaches to the Uncanny}

At the turn of the $20^{\text {st }}$ century the uncanny covered a broad spectrum of problems in various fields of study from "political and social alienation" to "disturbing unhomeliness" (Masschelein 2011, 147). The uncanny started to be perceived as a literary concept as it became an integral part of today's literature and literary theory. Harold Bloom takes notice of Freud's contribution to "aesthetics, literary criticism and theory, but, above all, [...] to the resistant strangeness of literature” (Royle 2003, 15). One might even say that literature and the uncanny are interdependent as one is haunted by another, taking into consideration the fact that Freud's examples in his psychoanalytical essay were based purely on literature. David Farell Krell even claims that they are "marvellously narrated and beautifully crafted pieces of writing" (Royle 2003, 52, 14-15). The new figures such as "cyborg or technologically enhanced human" were added in literature and literary studies to already existing motifs of the double and robotics, where the protagonists are usually haunted by the past and have to deal with trauma and the loss of identity (Masschelein 2011, 149). Masahiro Mori introduced the uncanny in the robotics and at the same time popularized the concept of the uncanny valley. As he put it, the term uncanny valley refers to "the [...] relation between the human likeness of an entity and the perceiver's affinity for it" (Mori 2012, 2). Jentsch drew similar conclusions in "On the Psychology of the Uncanny" and the following passage proves the significance of his intellectual uncertainty and the notion of psychical helplessness in development of the uncanny in the field of modern technology, as it constantly casts doubts on Cartesianism:

Among all the psychical uncertainties that can become a cause for the uncanny feeling to
arise, there is one in particular that is able to develop a fairly regular, powerful and very
general effect: namely, doubt as to whether an apparently living being really is animate and,
conversely, doubt as to whether a lifeless object may not in fact be animate (Jentsch 2008, 221).

Mori's modernized concept has been put into use in the entertainment industry where technology correlates with the uncanny narratives. The uncanny valley flourishes in cinematography, especially in science fiction movies and animations for children that are fulfilled with uncanny creatures (Masschelein 2011, 147-152). 


\section{Conclusion}

Sigmund Freud popularized the concept of the uncanny by claiming that something can be familiar and unfamiliar at the same time but the uncanny itself is much more than just the experience of alienation or uncertainty. The ideas of the uncanny find application in such fields as "art and literature, film, cultural studies and sexual difference" (Royle 2003, 12-13). In the past, the uncanny could be manifested in the form of mental disorders, inanimate objects, the figure of the double and fear of the dead but nowadays it tackles the issues of cloning, body transformation, literature, religion and politics (Royle 2003, 1-3). Freud was the first who brought attention to the dualistic nature of the word, focusing on the semantics of heimlich and its antonym. The ambiguity of the German word unheimlich and the translators' selection of the uncanny for the strange contributed to the creation of various theories and connected the Freudian theory with literature of the fantastic and literary criticism. The uncanny has indeed gone a long way from 1906 and it seems that each re-reading of Freud's "The Uncanny" brings to light new interpretations of the concept.

\section{References}

Barnaby, Andrew. 2015. "After the event: Freud's uncanny and the anxiety of origins". The Psychoanalytic Quarterly 84(4): 975-1006.

Bronstein, C., Seulin, C. 2020. On Freud's “The Uncanny”. Abingdon, Oxon: Routledge.

Cixous, Hélène. 1976. "Fiction and its phantoms: A reading of Freud's Das Unheimliche (The 'Uncanny')." New Literary History 7(3): 525-645.

Derrida, Jacques. 1994. Specters of Marx: The State of the Debt, the Work of Mourning and the New International, trans. Peggy Kamuf. New York and London: Routledge.

Freud, Sigmund. 1919. “The Uncanny”, trans. James Strachey. (https://webcache.googleuse rcontent.com/search?q=cache:LYw_sG7pTJss:https://web.mit.edu/allanmc/www/freud1.pdf $+\& c d=1 \& h l=p l \& c t=c l n k \& g l=p l \& c l i e n t=f i r e f o x-b-d)$.

Jentsch, Erst. 2008. “Document: 'On the psychology of the uncanny' (1906), by Ernst Jentsch”, trans. Roy Sellars. In Uncanny Modernity: Cultural Theories, Modern Anxieties, edited by Jo Collins and John Jervis. Basington: Palgrave Macmillan.

Masschelein, Anneleen. 2011. The Unconcept: The Freudian Uncanny in Late-Twentieth-Century-Theory. Albany: State University of New York.

Mori, Masahiro. 2012. "The Uncanny Valley [From the Field]", trans. Karl MacDorman and Norri Kageki. In IEEE Robotics \& Automation Magazine 98-100.

Royle, Nicholas 2003. The Uncanny. Manchester: Manchester University Press.

Todorov, Tzvetan. 1973. The Fantastic. A Structural Approach to a Literary Genre. Cleveland/London: The Press of Case Western Reserve University. 